\section{Peter Mahaffy Awarded 3M Canada Teaching Fellowship}

ing's University College chemistry professor Peter Mahaffy has been awarded the 3M Canada Teaching Fellowship, which honors educational leadership and excellence in undergraduate teaching. The 3M Fellowship is regarded as Canada's top teaching award.

Mahaffy was recognized for his contributions to the learning community at King's University College and for his leadership in international

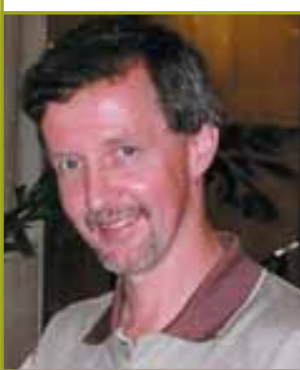

Peter Mahaffy. science education.

"It is gratifying to see Mahaffy's teaching excellence recognized with such a celebrated award," said King's President Harry Fernhout. "His contributions at both the national and international level are a reflection of the amazing work he does right here at King's. His approach to teaching both inspires our students and serves as a model for university professors far and wide. We are privileged to have him as part of our team."

"Professor Mahaffy's passion for chemistry has made him a visionary science educator," noted King's Vice-President Academic, Dr. Harry Spaling. "Mahaffy uses a wide range of teaching techniques to connect with learners. Even more importantly, he is such a gifted teacher because he authentically values his relationship with students. He has an unsurpassed ability to inspire all students, including nonscience majors, to articulate an understanding of the scientific world."

Mahaffy works both with chemistry majors in the nationally accredited chemistry program at King's, and has developed innovative approaches to teaching chemistry to arts and science students. As one of the early adaptors of molecular modeling for teaching purposes, he continues to collaborate with colleagues at the King's Centre for Visualization in Science to develop eye-catching visualizations and other teaching aids now used around the world.

One of Mahaffy's significant contributions is a new metaphor for chemistry education. His tetrahedral model incorporates the existing triangle metaphor that learners encounter in their chemistry textbooks, but extends the triangle in a third dimension, representing the human contexts for chemistry. Chemical educators have embraced this new metaphor, and organizers of major international conferences have invited Mahaffy to describe this new approach to chemistry education.

Mahaffy's roles as chair of IUPAC's Committee on Chemistry Education and as a member of the International Council on Science's Committee on Freedom and Responsibility in the Conduct of Science place him in global leadership positions in science education and science policy. During his 28-year career as a chemistry professor, Dr. Mahaffy has been described as "Mister Chemical Educator."

"If there is any area of professional success that is by definition never an individual achievement, it is in the rewarding world of teaching and learning," says Mahaffy. "It is such a privilege to work with inspirational students and colleagues in our supportive learning community at King's, and with international collaborators to use the tools of science and science education to help make the world a better place."

iiij www.kingsu.net/page.aspx?ID=97209

Pieter S. Steyn Receives Science for Society Gold Medal

ormer IUPAC President Piet Steyn (2002-2003) was awarded the 2007 Science for Society Gold Medal from the Academy of Science of South Africa (ASSAf) at a ceremony held 26 November 2007 in Pretoria, South Africa. Two medals are awarded annually to individuals from South Africa who apply

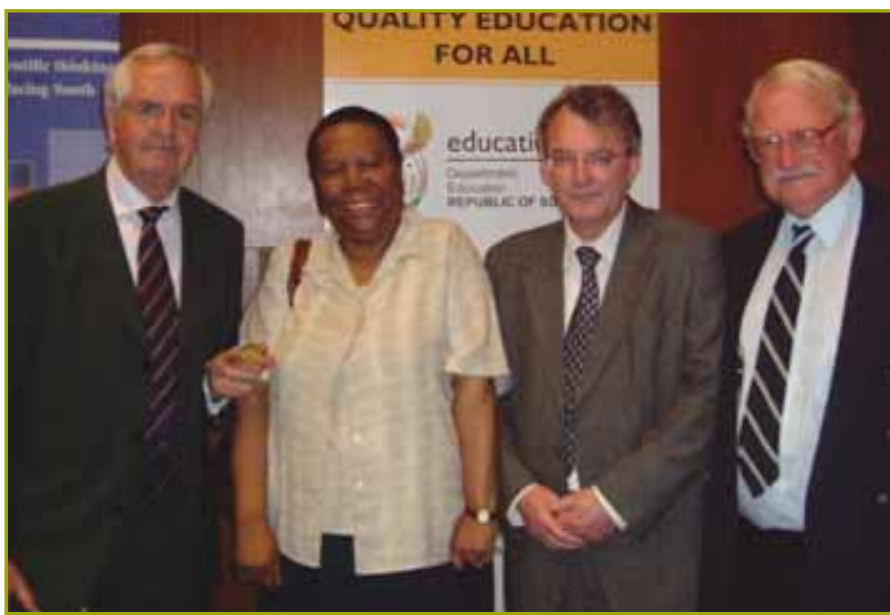

Piet Steyn (left), holding his ASSAf 2007 Science for Society Gold Medal, Naledi Pandor (minister of Education), Robin Crewe (president of ASSAf), and Wieland Gevers (chief executive officer of ASSAf). 